\title{
Estudo dos potenciais evocados auditivos em autismo*****
}

\author{
Study of auditory evoked potentials in autism
}

Fernanda Cristina Leite Magliaro*

Claudia Inês Scheuer**

Francisco Baptista Assumpção Júnior***

Carla Gentile Matas****

*Fonoaudióloga. Doutora em Ciências pelo Programa de Pós-Graduação em Ciências da Reabilitação do Departamento de Fisioterapia, Fonoaudiologia e Terapia Ocupacional da Faculdade de Medicina da Universidade de São Paulo (FMUSP). Pesquisadora Colaboradora do Laboratório de Investigação Fonoaudiológica em Potenciais Evocados Auditivos do Curso de Fonoaudiologia da FMUSP. Endereço para correspondência: R. Deolinda Rodrigues, 171 - Apto. 44 - Bloco A São Paulo - SP - CEP 05372-100 (fcmagliaro@usp.br).

**Fonoaudióloga. Doutora em Linguística pela Faculdade de Filosofia, Letras, Ciências Sociais e História da USP. Docente Aposentada do Departamento de Fisioterapia, Fonoaudiologia e Terapia Ocupacional da FMUSP.

***Médico. Professor Livre Docente pelo Departamento de Psiquiatria da FMUSP. Professor Associado do Departamento de Psicologia Clínica do Instituto de Psicologia da USP.

****Fonoaudióloga. Doutora em Ciências dos Distúrbios da Comunicação Humana pelo Programa de Pós-Graduação em Distúrbios da Comunicação Humana da Universidade Federal de São Paulo. Professora Assistente Doutora do Curso de Fonoaudiologia da USP.

*****Trabalho Realizado no Laboratório de Investigação Fonoaudiológica em Potenciais Evocados Auditivos do Departamento de Fisioterapia, Fonoaudiologia e Terapia Ocupacional da FMUSP.

Artigo Original de Pesquisa

Artigo Submetido a Avaliação por Pares

Conflito de Interesse: não

Recebido em 30.04.2009.

Revisado em 19.10.2009; 18.12.2009; 23.12.2009.

Aceito para Publicação em 01.02.2010.

\section{Abstract}

Background: electrophysiological assessment of hearing in autistic individuals. Aim: to characterize the findings obtained in the electrophysiological assessments of autistic individuals, as well as to compare these to the results obtained for individuals of the same age who present typical development. Method: 16 individuals with autism (study group) and 25 normal individuals (control group), ranging in age from eight to 20 years underwent anamnesis, pure tone audiometry, speech audiometry, acoustic immitance measures, brainstem auditory evoked potential (BAEP), middle latency response (MLR) and cognitive potential (P300). Results: the study group presented altered results in all auditory evoked potentials, showing statistically significant differences when compared to the control group. Concerning the types of alterations found in the study group the following results were observed: higher occurrence of lower brainstem alteration in the BAEP, both (electrode and ear effects occurring simultaneously) in the MLR, and absence of response in the P300. In the quantitative data analysis, statistically significant differences between the groups were found only for the BAEP regarding the latencies of waves III and V and interpeaks I-III and I-V. Conclusion: autistic individuals present altered BAEP and P300, suggesting impairment in the brainstem auditory pathway and corticals / subcorticals areas.

Key Words: Auditory Evoked Potentials; Audiometry; Autistic Disorder; Pervasive Child Development Disorders.

\section{Resumo}

Tema: avaliação eletrofisiológica da audição em indivíduos com autismo. Objetivo: caracterizar os achados das avaliações eletrofisiológicas da audição em indivíduos com autismo, bem como comparar seus resultados aos obtidos em indivíduos com desenvolvimento típico da mesma faixa etária. Método: foram realizadas anamnese, audiometria tonal, logoaudiometria, medidas de imitância acústica, potenciais evocados auditivos de tronco encefálico (PEATE) e de média latência (PEAML), e potencial cognitivo (P300), em 16 indivíduos com autismo (grupo pesquisa) e 25 normais (grupo controle), com idades entre oito e 20 anos. Resultados: o grupo pesquisa apresentou resultados alterados em todos os potenciais evocados auditivos, havendo diferença estatisticamente significante quando comparado ao grupo controle. Foi observada uma maior ocorrência de alteração do tipo tronco encefálico baixo no PEATE, do tipo Ambas no PEAML, e ausência de resposta no P300, para o grupo pesquisa. Na análise dos dados quantitativos, verificou-se que apenas para o PEATE ocorreu diferença estatisticamente significante entre os grupos, com relação às latências das ondas III e V e interpicos I-III e I-V. Conclusão: indivíduos com autismo apresentam alterações no PEATE e P300, sugerindo comprometimento da via auditiva em tronco encefálico, áreas subcorticais e corticais.

Palavras-Chave: Potenciais Evocados Auditivos; Audiometria; Transtorno Autístico; Transtornos Globais do Desenvolvimento Infantil. 


\section{Introduction}

According to DSM-IV (Diagnostic and Statistical Manual of Mental Disorders) (1), the autistic disorder is characterized by an abnormal or impaired development in social interaction and communication. According to Ritvo (1976) (2), autism is a developmental disorder caused by an alteration in the central nervous system, which can cause impairments on perception, social interaction, among others. Studies report different findings regarding electrophysiological hearing tests in individuals with autism. Among such findings, one can cite alterations in brainstem auditory evoked potentials $(3,4,5,6,7,8,9,10,11,12,13)$ and long latency auditory evokedpotentials $(14,15,16,17,18)$.

Auditory Evoked Potentials (AEP) are objective measures that analyze the neuroelectric activity along the auditory pathway (from the auditory nerve to the cortex) in response to an acoustic stimulus (19). The AEP can be classified as short, medium, and long latency potentials (20).

Because individuals with autism may exhibit perceptual, attention and memory impairments, they might sometimes be misdiagnosed as hearing impaired. Therefore, it is necessary to identify alterations in the central auditory system through objective tests in order to provide an accurate diagnosis and a more effective intervention, which will determine a smaller reduction in quality of life of these individuals.

The purpose of this study was to characterize the findings of electrophysiological hearing assessment in individuals with autism and to compare these findings to those obtained in typically developing individuals.

\section{Method}

This research consisted on a cross-sectional, prospective, observational and descriptive study. The research project was approved by CAPPesq-HCFMUSP (No. 237/03). All parents or guardians signed an Informed Consent prior to the beginning of procedures.

The study included 41 subjects aged between eight and 20 years with normal hearing thresholds, divided into two groups: Study Group (SG) composed by 16 individuals (one female and 15 male) with autism and mean age of 11.94 years; and Control Group (CG) composed by 25 individuals (16 females and nine males) with typical development, no psychiatric, neurological, language, auditory, and auditory processing complaints and mean age of 12.16 years.

Participants were selected to compose SG from a list of current patients of the Department of Psychiatry IPQ - HC FMUSP and the Language and Cognition Laboratory, FMUSP. Specific inclusion criteria to this group were: medical diagnosis of autism; childhood autism; Asperger syndrome or high-functioning autism according to DSM IV (1); absence of neurological diseases; currently under psychiatric treatment; and presence of social interaction skills necessary to perform the basic audiological assessment.

\section{Procedures}

Anamnesis (interview with parents or guardians) and conventional audiological assessment were carried out. The audiological assessment was composed by the following:

- Visual inspection of the external auditory canal with otoscope Heine;

- Immitance testing (tympanometry and ipsilateral acoustic reflexes at $500,1000,2000,4000 \mathrm{~Hz}$, frequency of $226 \mathrm{~Hz}$ ) with the middle ear analyzer Grason-Stadler, GSI-33(ANSI S3 .39-1987);

- Theshold Tonal Audiometry (frequencies from 250 to $8000 \mathrm{~Hz}$ ); Speech Recognition Threshold (SRT) and Percentage Speech Recognition Index (SRI) (21) with the audiometers GSI-61 and GSI-68 from Grason -Stadler, TDH-50 supra aural headphones (ANSI S3.6-1989 and IEC-1988), and soundproof booth (ANSI S3.1-1991).

Instructions concerning the audiological tests were provided and reinforced to all participants during the procedures.

The hearing electrophysiological assessment was carried out after normal hearing was verified thresholds bellow $25 \mathrm{~dB}$ for all frequencies tested and speech audiometry and acoustic immittance measures within normal range $(21,22)$. Electrophysiological assessment was carried out with the equipment model Traveler Express from Biologic. The test was performed with the participant seated in a recliner chair in an acoustically and electrically treated room. The electrophysiological assessments were performed under appropriate conditions, without the use of sedation. The maximum value of artifacts accepted was $10 \%$ of the total stimuli presented at each potential. The skin (forehead, mastoid, and scalp) was cleaned with abrasive paste and the electrodes were placed on the skin according to the standard International Electrode System (IES) 10-20 (23) for each potential analyzed. The acoustic stimuli were presented through supra-aural phones and the values of electrode impedance were below $5 \mathrm{kOhms}$. In this test, the following potentials were analyzed: P300, middle latency response (MLR), and brainstem auditory evoked potential (BAEP). The potentials 
were performed in this sequence to ensure the individual's attention to the first two tests.

The tone-burst stimulus presented monaurally at $75 \mathrm{~dB}$ nHL at a presentation rate of 1.1 stimuli per second (total of 300 stimuli) was used for the P300. The frequent stimulus (80\%) was presented at 1000 $\mathrm{Hz}$ and the rare one (20\%) at $1500 \mathrm{~Hz}$. The participant was instructed to be attentive to the rare stimulus that randomly appeared within a series of frequent stimuli. They were asked to count aloud the number of times the rare stimulus occurred. A brief training was performed before the examination to ensure understanding of the test procedures. The latency of P300 wave was used to analyze this potential.

The acoustic click stimuli presented monaurally at $70 \mathrm{~dB} \mathrm{nHL}$ at a presentation rate of 9.9 clicks per second (total of 1000 stimuli) was used for MLR. The Na-Pa amplitudes were analyzed in the various studied modalities (C3/A1, C3/A2, C4/A1, C4/A2).

The acoustic click stimulus with rarefied polarity presented monaurally at $80 \mathrm{~dB}$ nHL at a presentation rate of 19.0 stimuli per second and with duration of $0.1 \mathrm{~ms}$ (total of 2000 stimuli) was used for the BAEP. Latencies of waves I, III and V, and interpeak I-III, III-V and IV were analyzed according to normal standards values presented in Table 1.

\section{Data Classification}

For the BAEP, latencies of waves I, III, V and interpeaks I-III, V, IV in each ear were identified and analyzed. The individual was classified as normal or abnormal based on standard values from Chart 1 . The alterations were classified into: low brainstem (LB); high brainstem (HB) or both (concurrent occurrence of LB and HB alteration).

Regarding the MLR, the Na and Pa waves were identified and analyzed in terms of C3/A1, C3/A2, C4/A1, C4/A2. The waves were compared two by two. A difference less than or equal to $50 \%$ between the amplitudes obtained in each comparison was indicative of normality (24). The alterations were classified into: ear effect (EE), electrode effect (ELE); or both (concurrent occurrence of EE and ELE in the same participant).

The P300 wave latency was identified and analyzed at the curve of the rare stimulus for each ear. Participants were classified as normal or abnormal according to normal values proposed in the literature (25) for each age group. The alterations were classified into: delayed, absent, or both (concurrent occurrence of delayed and absent in the same participant).

The participant was considered altered when at least one of the ears, or one of the sides, presented alterations.

The qualitative data analysis was carried out through the between and within groups comparison of normal and altered results for all AEP. The types of alterations observed were analyzed. For such, the two proportions test and the confidence intervals for proportions were used.

The quantitative data analysis was carried out through the observation of mean, median, standard deviation, lower limit, upper limit, maximum and minimum results of each AEP, for each group. The between groups analysis for the mean was carried out and their levels of significance were tested. The significance level adopted was of 0.05 (5\%). ANOVAs and confidence intervals for the mean were calculated.

CHART 1. BAEP latency and interpeak normal standards for individuals above 24 months of age proposed by the evoked potential user manual.

\begin{tabular}{|c|c|c|c|c|c|c}
\hline & Wave I & Wave III & Wave V & Interpeak I-III & Interpeak III-V Interpeak I-V \\
\hline Mean (ms) & 1,54 & 3,69 & 5,54 & 2,14 & 1,86 \\
\hline $\begin{array}{c}\text { Standard } \\
\text { Deviation (ms) }\end{array}$ & 0,11 & 0,10 & 0,19 & 0,23 & 0,14 \\
\hline
\end{tabular}




\section{Results}

\section{1 - BAEP}

No statistically significant difference was observed in the comparison between the right and left ears of the absolute latencies of waves I, III and $\mathrm{V}$ and interpeak I-III, V, and IV in both groups. Therefore, the right and left ears were grouped, in each group, and the mean values of latencies and interpeaks were compared.

There was an statistically significant difference between CG and SG regarding the latencies of waves III and V and interpeaks I-III and IV (quantitative data analysis) (Table 1) as well as regarding the altered results (qualitative data analysis) (Table 2).

In the SG, the most frequent type of alteration was the LB (83.3\%) considered statistically significant when compared to the types HB $(0 \%)$, and both (16.7\%).

\section{2-MLR}

The Na-Pa amplitudes of MLR were compared (quantitative data analysis) among the modalities (C3/A1, C3/A2, C4/A1, C4/A2). No statistically significant between and within groups differences were observed.

A statistically significant difference (Table 2) was observed when comparing the normal and abnormal results (qualitative data analysis) between the groups. In the CG, we observed that the most frequent type of alteration was both (75.0\%), being considered statistically significant different in comparison to the other types (EE 6.3\% and ELE 18.8\%). In the SG, the most frequent type of alteration was also both (60.0\%) although this effect was statistically significant only for ELE (0\%).

\section{3-P300}

There was no statistically significant difference between right and left ears for the P300 wave in both CG and SG. Thus, the ears were grouped for the between groups comparison. There was no significant difference between CG and SG (quantitative data analysis).

Statistically significant difference was observed between CG and SG for the result of altered P300 (qualitative data analysis) (Table 2). In the SG, the absence of response (60.0\%) was the predominant type of alteration and it was statistically significant only in comparison to the type both ( $0 \%)$. 
TABLE 1. Between-groups comparison of BAEP latencies of waves I, III and V and interpeaks I-III, III-V and IV

\begin{tabular}{|c|c|c|c|c|c|c|c|c|c|c|}
\hline \multicolumn{2}{|c|}{ BAEP } & \multirow{2}{*}{$\begin{array}{c}\text { Mean } \\
1,52\end{array}$} & \multirow{2}{*}{$\begin{array}{c}\text { Median } \\
1,52\end{array}$} & \multirow{2}{*}{$\begin{array}{c}\text { Standard } \\
\text { Deviation }\end{array}$} & \multirow{2}{*}{$\begin{array}{c}\text { Minimum } \\
1,36\end{array}$} & \multirow{2}{*}{$\begin{array}{c}\text { Maximum } \\
1,84\end{array}$} & \multirow{2}{*}{$\begin{array}{c}\mathbf{n} \\
50\end{array}$} & \multirow{2}{*}{$\begin{array}{c}\begin{array}{c}\text { Inferior } \\
\text { Limit }\end{array} \\
1,49\end{array}$} & \multirow{2}{*}{$\begin{array}{c}\begin{array}{c}\text { Superior } \\
\text { Limit }\end{array} \\
1,54\end{array}$} & \multirow{3}{*}{$\begin{array}{c}\begin{array}{c}\mathrm{p}- \\
\text { value }\end{array} \\
0,124\end{array}$} \\
\hline & Control & & & & & & & & & \\
\hline Wave I & Study & 1,55 & 1,56 & 0,07 & 1,40 & 1,68 & 32 & 1,52 & 1,57 & \\
\hline \multirow{2}{*}{ Wave III } & Control & 3,61 & 3,60 & 0,10 & 3,44 & 3,80 & 50 & 3,59 & 3,64 & \multirow{2}{*}{$\underset{*}{<0,001}$} \\
\hline & Study & 3,73 & 3,74 & 0,11 & 3,56 & 3,92 & 32 & 3,70 & 3,77 & \\
\hline \multirow{2}{*}{ Wave V } & Control & 5,59 & 5,60 & 0,11 & 5,40 & 5,80 & 50 & 5,56 & 5,62 & \multirow{2}{*}{$\underset{*}{<0,001}$} \\
\hline & Study & 5,69 & 5,68 & 0,12 & 5,44 & 5,92 & 32 & 5,65 & 5,73 & \\
\hline \multirow{2}{*}{$\begin{array}{l}\text { Interpeak } \\
\text { I - III }\end{array}$} & Control & 2,09 & 2,10 & 0,11 & 1,84 & 2,28 & 50 & 2,07 & 2,12 & \multirow{2}{*}{$0,001^{*}$} \\
\hline & Study & 2,18 & 2,16 & 0,12 & 2,00 & 2,48 & 32 & 2,14 & 2,23 & \\
\hline \multirow{2}{*}{$\begin{array}{l}\text { Interpeak } \\
\text { III -V }\end{array}$} & Control & 1,98 & 1,96 & 0,07 & 1,88 & 2,16 & 50 & 1,96 & 1,99 & \multirow{2}{*}{0,227} \\
\hline & Study & 1,96 & 1,96 & 0,08 & 1,80 & 2,12 & 32 & 1,93 & 1,98 & \\
\hline \multirow{2}{*}{$\begin{array}{l}\text { Interpeak } \\
\mathrm{I}-\mathrm{V}\end{array}$} & Control & 4,07 & 4,08 & 0,10 & 3,84 & 4,24 & 50 & 4,04 & 4,10 & \multirow{2}{*}{$0,006^{*}$} \\
\hline & Study & 4,14 & 4,12 & 0,12 & 4,00 & 4,48 & 32 & 4,10 & 4,18 & \\
\hline
\end{tabular}

* p-value considered statistically significant

BAEP: Brainstem Auditory Evoked Potential

TABLE 2. Distribution of occurrence of normal and abnormal results on BAEP, MLR and P300 in the control and study groups.

\begin{tabular}{|c|c|c|c|c|c|c|c|c|}
\hline & & \multicolumn{3}{|c|}{ Control Group } & \multicolumn{3}{|c|}{ Study Group } & \multirow{2}{*}{ p-value } \\
\hline & & $\mathbf{n}$ & $\%$ & var & $\mathbf{n}$ & $\%$ & var & \\
\hline \multirow{2}{*}{ BAEP } & Normal & 25 & $100,0 \%$ & \multirow{2}{*}{$0,0 \%$} & 10 & $62,5 \%$ & \multirow{2}{*}{$23,7 \%$} & \multirow{2}{*}{$<0,001^{*}$} \\
\hline & Abnormal & 0 & $0,0 \%$ & & 6 & $37,5 \%$ & & \\
\hline \multirow{2}{*}{ MLR } & Normal & 9 & $36,0 \%$ & \multirow{2}{*}{$18,8 \%$} & 11 & $68,8 \%$ & \multirow{2}{*}{$22,7 \%$} & \multirow{2}{*}{$0,041 *$} \\
\hline & Abnormal & 16 & $64,0 \%$ & & 5 & $31,3 \%$ & & \\
\hline \multirow{2}{*}{ P300 } & Normal & 25 & $100,0 \%$ & \multirow{2}{*}{$0,0 \%$} & 11 & $68,8 \%$ & \multirow{2}{*}{$22,7 \%$} & \multirow{2}{*}{$0,003^{*}$} \\
\hline & Abnormal & 0 & $0,0 \%$ & & 5 & $31,3 \%$ & & \\
\hline
\end{tabular}

*p-value considered statistically significant ; BAEP: Brainstem Auditory Evoked Potential; MLR: Middle-Latency Response; P300: Cognitive Potential; $\mathrm{n}$ = number; var = variability index of the mean 


\section{Discussion}

\section{1 - BAEP}

Table 1 displayed an increase in absolute latencies of waves III and V and interpeaks I-III and I-V in the SG as compared to the CG. These findings are in agreement with studies that observed an increase in BAEP latencies of waves III (3) and V $(6,12)$ and interpeaks I-III $(11)$ and I-V $(4,9,12)$ in individuals with autism.

We can observe in table 2 that the SG presented abnormal results, agreeing to the study that indicated brainstem dysfunction in autistic individuals (6). For the SG, the alterations type LB were the most frequently observed ones. Thus, the results described above suggest that individuals with autism have a delay in the conduction of the acoustic stimulus at the low brainstem region $(3,4,5,7,9,11)$.

Similar findings have been reported by a study in which more than half $(58.4 \%)$ of autistic individuals with normal hearing showed abnormalities in BAEP - delayed wave $\mathrm{V}$ and interpeak I-V extension. The authors concluded that these alterations may occur due to dysfunction of the brainstem auditory pathway, or even due to the involvement of the cochlear efferent system (10).

\section{2 - MLR}

Table 2 displayed that the CG presented more abnormal results than the SG did. Since MLR is clinically useful in the assessment of auditory processing (AP) disorders (26,27), we hypothesize here that individuals in the CG could present AP alterations, which would justify the results.

Individuals with autism have as behavioral characteristics perception, development, social networking and speech and language disorders (2) which may all be related to changes in AP. Thus, the MLR alterations observed probably reflected difficulties in processing auditory information in the subcortical and cortical auditory pathways.
3-P300

Table 2 displayed that the SG presented abnormal results on the P300, and the absence of response (AR) was the most frequently observed alteration followed by the Delayed Latency (DL) one. These findings suggest that P300 alterations in autistic individuals reflect their cognitive and attentional difficulties as the latency delay of this wave indicates the existence of a possible deficit in cognitive processing (28). The P300 is successfully generated as long as the individual is able to focus his/her attention on the rare stimuli (29). In the present study, we verified that autistic individuals had difficulties in focusing the attention on the rare stimuli. This finding confirms the attentional deficit in this population.

The literature reports a decrease in P200 and P300 components in autistic individuals, indicating that this population presents abnormalities on central aspects of auditory processing (involving registration and storage of auditory information) (14).

\section{Conclusion}

Given the findings of the present study, we can conclude that individuals with autism exhibit: BAEP alterations that suggest impairments on the auditory brainstem (cochlear nucleus and lateral lemniscus regions); sync alterations on neuroelectric pulse generation in this region; structural or functional alterations that interfere with the transmission of acoustic stimuli along the auditory pathway; P300 alterations suggesting involvement of the cortical auditory regions; cognitive processing, attention, auditory discrimination, or even memory deficits.

Further studies that assess the central auditory pathway of autistic individuals are necessary to better characterize the electrophysiological findings of this population. 


\section{References}

1. APA. Manual diagnóstico e estatístico de transtornos mentais - DSM-IV. Porto Alegre: Artes Médicas;1995. p.65-76.

2. Ritvo ER. Autism diagnosis, current research and management. New York: Spectrum Publications Inc; 1976.

3. Rosenblum SM, Arick JR, Krug DA, Stubbs EG, Young NB, Pelson RO. Auditory brainstem evoked responses in autistic children. J Autism Dev Disord.1980;10(2):215-25.

4. Taylor MJ, Rosenblatt B, Linschoten L. Auditory brainstem responses abnormalities in autistic children. Can J Neurol Sci. 1982;9(4):429-33.

5. Tanguay PE, Edwards RM, Buchwald J, Schwafel J, Allen V. Auditory brainstem evoked responses in autistic children. Arch Gen Psychiat. 1982;39(2):174-80.

6. Gillberg C, Rosenhall U, Johansson E. Auditory brainstem responses in childhood psychosis. J Autism Dev Disord. 1983;13(2):181-95.

7. Gillberg C, Steffenburg S, Jakobsson G. Neurobiological findings in 20 relatively gifted children with Kanner-type autism or Asperger Syndrome. Dev Med Child Neurol. 1987;29:641-9.

8. Sersen EA, Heaney G, Clausen J, Belser R, Rainbow S. Brainstem auditory- evoked responses with and without sedation in autism and Down's syndrome. Biol Psychiatry. 1990;27(8):834-40.

9. Maziade M, Mérette C, Cayer M, et al. Prolongation of Brainstem Auditory-Evoked Responses in Autistic Probands and Their Unaffected Relatives. Arch Gen Psychiat. 2000;57(11):1077-83.

10. Rosenhall U, Nordin V, Brantberg, Gillberg C. Autism and auditory brainstem responses. Ear Hearing. 2003;24(3):206-14.

11. Tas A, Yagiz R, Tas M, Esme M, Uzun C, Karasalihoglu A R. Evaluation of hearing in children with autism by using TEOAE and ABR. Autism. 2007;11:73-9.

12. Kwon S, Kim J, Choe B-H, Ko C, Park S. Electrophysiologic assessment of central auditory processing by auditory brainstem responses in children with austism spectrum disorders. J.Korean Med. Sci. 2007; 22:656-9.

13. Russo NM, Skoe E, Trommer B, Nicol T, Zecker S ,Bradlow A, Kraus N. Deficient brainstem encoding of pitch in children with Autism Spectrum Disorders. Clinical Neurophysiology. 2008:119:1720-31.

14. Novick B, Vaughan Jr HG, Kurtzberg D, Simson R. An electrophysiologic indication of auditory processing defects in autism. Psychiat Res. 1980;3(1):107-14.
15. Niwa S, Ohta M, Yamazaki K. P300 and stimulus evaluation process in autistic subjects. J Autism Dev Disord. 1983;13(1):33-42.

16. Bruneau N, Roux S, Adrien JL, Barthélémy C. Auditory associative córtex dysfunction in children with autism: evidence from late auditory evoked potentials (N1 wave T complex). Clin Neurophysiol. 1999;110:1927-34.

17. Bruneau N, Bonnet-Brilhaut F, Gomot M, Adrien JL, Barthélémy C. Cortical auditory processing and communication in children with autism: electrophysiological/behavioral relations. Int $\mathrm{J}$ Psychophysiol. 2003;51:17-25.

18. Whitehouse AJO, Bishop DVM. Do children with autism 'switch off' to speech sounds? An investigation using eventrelated potentials. Developmental Science. 2008:11(4):516-24.

19. Junqueira CAO, Frizzo ACF. Potenciais evocados auditivos e curta, média e londa latência. In: Aquino AMCM, org. Processamento auditivo - Eletrofisiologia e Psicoacústica. São Paulo: Lovise; 2002. p.63-85.

20. Ruth RA, Lambert PR. Auditory evoked potentials. Otolaryng Clin N Am. 1991;24(2):349-70.

21. Santos TMM, Russo ICP. Logoaudiometria. In: Santos TMM, Russo ICP. A prática da audiologia clínica. $3^{\mathrm{a}}$ ed. São Paulo: Cortez; 1991. p.73-88.

22. Carvallo RMM, Carvalho M, Ishida IM. Auditory profile in individuals with and without CAPD. In: 12th Annual Convention \& Exposition of the American Academy of Audiology. Chicago. USA; 2000. p195.

23. Hall III JW. Handbook of auditory evoked responses. Boston: Allyn and Bacon; 1992.

24. Musiek FE, Lee WW - Potenciais auditivos de média e longa latência - In: MusieK FE, Rintelmann WF, org. Perspectivas atuais em avaliação auditiva. São Paulo: Manole; 2001. p.239-56.

25. McPherson DL. Late potentials of the auditory system (evoked potentials). San Diego: Singular Publishing Group; 1996.

26. Özdamar Ö, Kraus N. Auditory middle-latency responses in humans. Audiology. 1983;22:34-49.

27. Schochat E. Potenciais evocados auditivos. In: Carvallo RMM. Fonoaudilogia Informação para a formação: Procedimentos em Audiologia. Rio de Janeiro: Guanabara Koogan; 2003. p.57-70.

28. Picton TW. The P300 wave of the human eventrelated potential. J Clin Neurophysiol. 1992;9:456-79.

29. Schochat E. Avaliação eletrofisiológica da audição. In: Ferreira LP, Befi-Lopes D, Limongi SCO, org. Tratado de fonoaudiologia. São Paulo: Rocca; 2004. p.656-68. 